\title{
COMPONENTS OF SUCCESSFUL TECHNOLOGY INFUSION
}

\author{
Sylvia Ann Bembry, Winston-Salem State University, bembrys@wssu.edu \\ Carolyn L. Anderson, Winston-Salem State University, andersonc@wssu.edu
}

\begin{abstract}
The objective of this study is to look at what affects our students' success in higher education. Specifically, teaching strategies and proper use of Technology Infusion resources will be described. The goal was to redesign a management information systems course that had been taken the sophomore year and is now in the freshman year paradigm.
\end{abstract}

Keywords: Learning Styles, Technology, Team Teaching, Teaching Strategies

\section{INTRODUCTION}

Universities are transforming the way they operate and are taking a stronger leadership role in campus planning and implementation efforts as technology takes an increased presence in all facets of higher education. Winston-Salem State University has implemented a new technology requirement rather than a computer requirement. Since technology is changing so rapidly, a decision was made to go with mobile devices to complement the university's wireless environment. The suggested equipment is reviewed on an annual basis. Hence, the plan is to keep pace with the latest technology.

The student body is diverse and requires an understanding of each student's learning style so that students are successful [1]. Therefore, an on-line learning styles instrument [2] was used to assess students' learning preferences. Team teachers took these preferences into account as each section of a class was facilitated.

\section{IMPORTANCE}

"Technology Infusion" was at the forefront of learning throughout all sections of the course. Technology was used as an aid to learning, instead of students learning without assistance. A description of available publishers' e-learning resources was discussed. Included in this discussion was how the resources were incorporated into several course sections; also, the students' action/reaction to the experience were reported. Data was gathered from each student using a learning styles instrument to get a better understanding of the diverse group of students. Hopefully, the experience and information will help other institutions of higher education meet the needs of students in a changing technological society.

\section{TEACHING STRATEGIES}

With diversity expanding, hundreds of different kinds of assessments have been developed to determine individual differences. Tests and surveys are designed to determine perceptual differences, learning styles, personality differences, and different kinds of talents. These materials are applied to help students to learn and teachers to facilitate more effectively.

For this course redesign, a scale to determine learning styles was administered to enrolled students. The learning styles inventory was developed by Dr. Richard Felder. He is the Hoechst Celanese Professor Emeritus of Chemical Engineering at North Carolina State University. The Learning Styles Inventory is an on-line instrument used to assess preferences on four dimensions (active/reflective, sensing/intuitive, visual/verbal, and sequential/global) [3]. Professors also took the inventory first in order to determine their own profile. The conclusion suggested a need to teach in different ways to make learning easy for students with different profiles. The four categories of learners are active/reflective, sensing/intuitive, visual/verbal, and sequential/global. The array of teaching strategies (e.g., lecture, problem solving, show/tell) was broadened so that students were learning at least part of the time in ways they found comfortable and at other times in ways that stretched them into new ways of thinking and learning.

For example, to assist active/reflective learners, group work was developed so that they could work with others to develop and design projects. This helped them to retain information better by finding ways to immediately apply what they had learned. Connections were made to real world problems to help the sensing learner.

Technology is good for visual learners. Concepts are presented and visual/verbal students may use the many technological devices to reinforce what has been presented. One way to ensure a return on 
investment is to apply technology at the appropriate level.

Sensing/intuitive students do better when they see how the learned concepts relate to real world situations. Infusing technology allowed students to apply what they had learned in and out of class.

A step-by-step process worked for sequential/global students. Students were able to logically outline material for the semester and see the larger picture. Then they were able to study individual topics realizing what details to study.

The Microcomputer Application course is a freshman-level course with a few sophomores, juniors and seniors enrolled. Initially, faculty used the blackboard during lectures. During 2003, PowerPoint presentations and real world problems were used in delivering basic knowledge about a topic that was then covered in more depth in a computer lab for reinforcement.

\section{TECHNOLOGY INFUSION RESOURCES}

Traditional university classroom resources are available; however, in selected courses throughout the university, technology resources are also being utilized. Since 2003, a Course Management System (CMS), Blackboard online teaching and learning software, desktop PCs, wireless tablets, and audio lectures are used to enhance the experiences in the business course "Microcomputer Applications." Blackboard is designed to transform the Internet into a powerful environment for the educational experience. A CMS enables faculty and students to access advanced teaching and learning capabilities, maximizing technology investments, and accessing course content beyond traditional boundaries.

A CMS is designed to mirror and support the existing structure, operations, and goals of the university. The system includes a broad range of course development and delivery capabilities, groundbreaking content management capabilities, and powerful learning information management capabilities-all supported by an extensible, state-of-the-art architecture.

\section{USES OF TECHNOLOGY RESOURCES AND STRATEGIES}

To provide a more responsive and seamless IT classroom environment, the university is becoming more student-centered and better equipped to monitor and improve student satisfaction and overall quality of education for students.

The Center for Innovative Teaching, Technology, Learning and Evaluation (CITTLE) at the university found affordable and powerful devices, ranging from next generation cell phones to PDAs, tablet PCs, and wireless networks. These technologies provide greater choice, flexibility, and convenience for an enriching educational experience. Students often purchased these devices and used them in and out of class to assist with course projects.

In addition to state-of-the-art devices, software selection is crucial. Blackboard licenses and supports integrated software designed to advance educational innovation. Blackboard's e-Education platform enables the university to align IT strategies with educational outcomes and institutional strategic objectives.

\section{METHODOLOGY}

A departure from traditional disciplinary course structure is occurring and technology is being placed at the center of what is done in academia. University personnel efforts are underway to develop objectives and projects leading to an appropriate and effective application of technology in the educational process. Planning, organizing, and implementing are at the forefront for many universities. Knowing students' learning styles and products will benefit the development of effective instructional delivery strategies and design by faculty. With this in mind, several sections of the course "Microcomputer Applications" were designed and taught with technology resources. Results from several aspects of the course are described, analyzed, and reported.

The course was taught by a team and received support from administration to do so. During the Summer 2003, faculty met and planned for the upcoming fall semester. The way the course was taught, students' learning styles [4] and instructor concerns were described and discussions for the redesigned course emerged. The ideas were tested during the Fall 2003 semester while it was still a sophomore level course. When the majority of the enrolled students were freshman, the faculty refined the course during the Spring 2004 and Spring 2006 semesters. Face-to-face instruction continues in the course and technology experiences are supplementary. Comparative data are collected to help with identifying and incorporating the components for successful technology infusion and teaching strategies in the course. 


\section{SURVEY AND CLASSROOM RESULTS}

Students process information differently. Felder describes these differences in eight learning styles. There is overlap, but in general, students fall into one of the categories. First, a student is described as active or reflective. Active learners usually retain and understand information best by doing something active with it, whereas reflective learners prefer to think about it quietly. Second, there are the sensing and intuitive learners. Sensing learners like learning facts, and intuitive learners prefer discovering possibilities and relationships. Third, visual learners remember best what they see, and verbal learners get more out of words. Finally, sequential and global learners tend to gain understanding in logical steps and learn in large jumps, absorbing material almost randomly without seeing connections and then suddenly getting it respectively.

Felder's learning style inventory was administered to the students; the results of the report are in Table 1.

Table 1. Percentage of Students per Learning Style

\begin{tabular}{lll} 
Learning Styles & \multicolumn{2}{c}{ Percent of Students } \\
\cline { 2 - 3 } & $\mathbf{2 0 0 3}$ & $\mathbf{2 0 0 6}$ \\
\hline Active & $75 \%$ & $74 \%$ \\
Reflective & $25 \%$ & $26 \%$ \\
Sensing & $76 \%$ & $77 \%$ \\
Intuitive & $24 \%$ & $23 \%$ \\
Visual & $84 \%$ & $77 \%$ \\
Verbal & $16 \%$ & $23 \%$ \\
Sequential & $88 \%$ & $74 \%$ \\
Global & $12 \%$ & $26 \%$
\end{tabular}

The comparison is between sophomores in 2003 and freshmen in 2006. More sophomore (84\%) are visual than freshmen $(77 \%)$, while more freshmen $(23 \%)$ are verbal than sophomores $(16 \%)$. Sequential students had a difference between freshmen $(74 \%)$ and sophomores $(88 \%)$. While there are differences in learning styles of freshmen and sophomores, students basically fall in the same categories. All categories of learning styles required the students to take action or an active part of his or her learning. Therefore, the technology infusion used for sophomores can also be used for freshmen.

Students were delighted to learn that emphasis would be placed on their personal learning styles once they completed the learning style inventory. In their minds, teachers seemed to care about how they learn, which implies that they would do better in the class
[5]. In addition, students approached projects differently once they knew their individual learning styles.

We are using the results to tailor our teaching styles and assigned projects to coincide with students' needs. Students are more responsive in class because they feel the team members were making a contribution to their success.

\section{SUMMARY}

Collaborating across campus through interdisciplinary team teaching allows the university initiative for technology requirement to be realized while reaching more students with more work and opportunities. Throughout the course, emphasis is placed on learning styles for appropriate technology infusion. Team teaching, for this technology infusion experience is confined to one class with multiple sections.

Planning occurred during the spring semester 2003 when a grant was applied for through faculty development. During the summer the team members met on several occasions. The traditional teaching method was described to help determine what works and how to incorporate Technology Infusion as a supplement. Curriculum change discussions were significant in the university core. "Microcomputer Applications" was changed from a sophomore-level course to a freshman-level course. Research on how to best meet freshmen needs had to be conducted. As a part of Technology Infusion, a learning styles inventory was administered to gather more information about the audience. The results show that the majority of the students are active, sensing, visual, and sequential learners. In addition to the preliminary planning, adjustments were made for teaching the course after learning how these groups of students learn.

\section{REFERENCES}

1. Price, L. (October 2004). Individual Differences in Learning: Cognitive control, cognitive style, and learning style. Educational Psychology, 24(5), 681-698.

2. Felder, R.M., \& Soloman, B.A. (1991). Index of Learning Styles, http://www.ncsu.edu/felder public/ILSpage.html.

3. Felder, R. M. \& Brent, R. (2005). Understanding Student Differences. Journal of Engineering Education, 94, 57-72.

4. Lo, J.J. \& Shu, P.C. (2005). Identification of Learning Styles Online by Observing Learners' 
Browsing Behavior Through a Neural Network. British Journal of Educational Technology, 36(1), 43-55.

5. Drennan, J. \& Pisarski, A. (July, August 2005).

Factors Affecting Student Attitudes Toward

Flexible Online Learning in Management
Education. The Journal of Educational Research, 98(6), 331-338. 